\title{
POLACY W OBLICZU TANATOSA - KONTYNUACJA I INNOWACJA WZORÓW KULTUROWYCH DOTYCZĄCYCH ŚMIERCI I UMIERANIA
}

\section{POLISH PEOPLE AND THANATOS - CONTINUATION AND INNOVATION OF CULTURAL PATTERNS RELATED TO DEATH AND DYING}

\author{
Emilia Zimnica-Kuzioła ${ }^{1(\mathrm{~A}, \mathrm{~B}, \mathrm{C}, \mathrm{D}, \mathrm{E}, \mathrm{F}, \mathrm{G})}$
}

\author{
${ }^{1}$ Uniwersytet Łódzki, Wydział Ekonomiczno-Socjologiczny, Instytut Socjologii
}

\begin{abstract}
Zimnica-Kuzioła E. (2017), Polacy w obliczu Tanatosa - kontynuacja i innowacja wzorów kulturowych dotyczących śmierci i umierania. Rozprawy Społeczne, 11 (2), s. 28-35.

Wkład autorów:

A. Zaplanowanie badań

B. Zebranie danych

C. Dane - analiza i statystyki

D. Interpretacja danych

E. Przygotowanie artykułu

F. Wyszukiwanie i analiza

literatury

G. Zebranie funduszy

Streszczenie

Celem artykułu jest socjologiczna refleksja zogniskowana wokół problematyki przemijania i śmierci. Odwołując się do ogólnopolskich reprezentatywnych badań, publikacji naukowych i popularnonaukowych, chciałbym pokazać specyfikę polskiego przeżywania żałoby, wierność tradycji, kultywowanie pamięci zmarłych i jednocześnie odnotować zmiany, jakim podlega dynamicznie rozwijający się przemysł funeralny. Osobne miejsce poświęcam możliwościom, jakie daje Internet $w$ zakresie społecznego wsparcia - tematyczne portale internetowe oferują wielokierunkową pomoc osobom przeżywającym żałobę.
\end{abstract}

Słowa kluczowe: umieranie i śmierć, przemysł funeralny, doświadczenie żałoby

\section{Summary}

The purpose of the following article is to provide a sociological reflection focusing on the problems of transience and death. By referring to representative surveys and specialist articles published in journals and on the Internet, I wish to present the specificity of Polish experience of grief, faith traditions, honoring the memory of the dead and, at the same time, note changes such as, for example, a dynamic growth of the funeral industry. Additionally, the paper indicates the existing social support in the form of numerous thematically arranged websites available on the Internet, which offer multidirectional help to those in mourning.

Keywords: death and dying, funeral industry, experiencing grief

\section{Tabele: 0}

Ryciny: 0

Literatura: 33

Otrzymano: 16.09.2016

Zaakceptowano: 28.11.2016 madzoną na jego temat. Co więcej-wiedza ta ciągle jeszcze jest bardzo nikła. Wiele problemów nie poddaje się warsztatowi badań naukowych lub nie mogą być one badane bez naruszania dobra osób umierających. Istniejące tabu śmierci, trudności rozmawiania na ten temat i uwikłane tu negatywne emocje sprawiają, że samo zagłębianie się w tę problematykę jest trudne dla wielu badaczy" (Ostrowska 2002, s. 273).

\section{Człowiek wobec śmierci \\ - teoria i badania empiryczne}

Wśród teoretyków-pionierów zajmujących się tą tematyką wymienić trzeba Zygmunta Freuda (koncepcja wrodzonego instynktu śmierci-Tanatosa), Emile`a Durkheima (studium socjologiczne na temat samobójstwa), Talcotta Parsonsa (śmierć jako fenomen wpływający na stabilizację systemu społecznego, w tym rodzinnego). Kilka książek z tej dziedziny zawdzięczamy Elisabeth Kubler-Ross, znanej choćby 
z opracowania teorii pięciu etapów umierania ${ }^{2}(D z i e-$ ci i śmierć, Koło życia, Rozmowy o śmierci i umieraniu, Śmierć. Ostatni etap rozwoju, Życiodajna śmierć). Warto wspomnieć także o analizach Anselma Straussa, Barneya Blasera, Hermana Feifela, Davida Sudnowa i Johna Hintona. W Polsce zainteresowanie tą problematyką przypada na lata siedemdziesiąte XX wieku (Tadeusz Kielanowski, Magdalena Sokołowska i Bogdan Kamiński). Jedną z ciekawszych prac jest książka Antoniny Ostrowskiej pt. Śmierć $w$ doświadczeniu jednostki $i$ społeczeństwa (pierwsze wydanie w roku 1991). Autorka przedstawia wyniki badań empirycznych (przeprowadzonych za granicą), własne obserwacje i pogłębiony namysł na temat umierania, przyjmując przy tym perspektywę jednostkową i zbiorową, bowiem śmierć jest tutaj nie tylko fenomenem indywidualnym, ale i społeczno-kulturowym, instytucjonalnym ${ }^{3}$.

W XX wieku śmierć stała się tematem tabu, zbyt trudnym, by można było o nim mówić bez lęku. Wiele czynników decyduje o przemianach kulturowych wzorów związanych z omawianą dziedziną, być może najważniejszym $\mathrm{z}$ nich jest przeobrażenie rodzin i wartości społecznych. Ostrowska pisze: „Wraz z zanikiem rodzin wielopokoleniowych zanika naturalny system opieki i oparcia dla ludzi starych i umierających, szansa obserwowania i przeżywania śmierci wraz z nimi. Zmianie uległa także struktura prestiżu w rodzinie; seniorzy nie pełnią w nich zaszczytnych ról, a ich choroby i cierpienia często nie są przedmiotem zainteresowania. Problem ten wiąże się z przemianami wartości społecznych otaczających starość. Zamiast symbolu mądrości życiowej, doświadczenia i rozwagi coraz częściej starość utożsamia się z niedołężnością, nieproduktywnością, uzależnieniem od innych. Jednoczesny wzrost takich wartości, jak: siła, młodość, sprawność, sukces, odwraca naszą uwagę od starości, a zatem także chorób i śmierci, które są na ogół jej udziałem" (Ostrowska 2005, s. 33).

\footnotetext{
${ }^{2}$ W książce opublikowanej w 1969 roku (On Death and Dying) E. Kubler-Ross wymienia nastepujące fazy w procesie świadomego umierania: zaprzeczenie i izolacja, gniew, negocjowanie (targowanie się), depresja, akceptacja (pogodzenie się z losem). Książka ukazała się w Polsce w 1979 roku, pt. Rozmowy o śmierci i umieraniu. Media Rodzina, Poznan 1979; uznana została nie tylko za "klasyczna pozycje literatury tanatologicznej", ale także za jedną z ważniejszych książek psychologicznych $\mathrm{XX}$ wieku.

Problemem hospicjów w Polsce zajął się m.in. J. Drążkiewicz (zredagował on książkę $W$ strone człowieka umierajacego. O ruchu hospicjów $w$ Polsce. Uniwersytet Warszawski, Instytut Socjologii, Warszawa 1989), a także autorzy artykułów zamieszczonych w pracy zbiorowe J. Kolbuszowski (red.) Problemy współczesnej tanatologii. Medycyna -Antropologia Kultury - Humanistyka. Wrocławskie Towarzystwo Naukowe, tom VI, Wrocław 2002 i tom VIII, Wrocław 2004). W 1996 roku ukazała się książka pod redakcją M. Gałuszki i K. Szewczyka Umierac bez lęku. Wstęp do bioetyki kulturowej. Wydawnictwo Naukowe PWN Warszawa). M. Ogryzko-Wiewiórowska opublikowała pracę Rodzina w obliczy śmierci. Studium socjologiczne. Wyd. UMCS, Lublin 1992). 0 samobójstwach w kontekście społecznej dezintegracji pisała M. Jarosz (Samobójstwa, Wydawnictwo Naukowe PWN, Warszawa 1997). Ważną pozycją z dziedziny socjologii medycyny jest książka M. Skrzypka Perspektywa chorego w socjologii choroby przewlekłej. Wyd. KUL, Lublin 2011. Autor podjął udana próbe „stworzenia teoretycznych podstaw socjologii doświadczenia choroby w kontekście paradygmatu interakcjonistyczno-interpretatywnego". Wyczerpująco omówił i przeanalizował zachodnie i polskie badania socjomedyczne dotyczące choroby przewlekłej.
}

Tematyka śmierci i umierania podejmowana była w sztuce: literaturze, malarstwie, filmie, rzeźbie, muzyce. Na gruncie filozofii dyskurs na temat przygodności ludzkiego istnienia rozpoczęli filozofowie starożytni i trwa on przez wieki aż do współczesności. Roman Ingarden (zm. w 1970 roku), wybitny przedstawiciel polskiej i światowej fenomenologii, wymownie pisał o skończoności człowieka i jego usytuowaniu w czasie, o skrytym w głębi każdej ludzkiej istoty lęku przed śmiercią: „Pogrążony w czasie, do siebie jako istoty niepodległej czasowi wiecznie tęskniący, człowiek czuje się zagrożony przemijaniem i niewiadomą nicościa jutra. Nie uświadamiając sobie tego, chce uciec od siebie, o sobie samym zapomnieć. Stara się nie wiedzieć, że nieuchronnie przemija, że z każda chwilą kończy się jak wypalający się żar. <Zabija czas>: wynajduje zajęcia, którymi by <wypełnił> czas, i całą uwagę swą koncentruje na robocie, bez której mógłby się obejść. By nie czuć się osamotniony i obcy na świecie, stwarza sobie fikcje obowiązku wobec czegoś, czego właściwie nie ma, co jest nieważne, ale co sam sobie wytworzył i czemu-nie przyznając się do tego-nadaje pozór doniosłości i istnienia. Odłogiem pozostawia samego siebie, by służyć czemuś innemu. Zamiast być przez pozostanie przy sobie, przez uchwycenie siebie w każdym bólu i w każdej radości, i w każdym wysiłku i zwycięstwie, zatraca się bezpowrotnie. Nie wie, jak wiele traci. Myśli, że buduje świat dokoła siebie i siebie w tym świecie, a tymczasem tłumi tylko własny lęk przed grożącą mu pustką" (Ingarden 2000, s. 332). Perspektywa końca życia rodzi bunt, niepokój, wyzwala mechanizmy wyparcia, nieudolne próby zapomnienia o tym, co nieuniknione. Człowiek jako „byt ku śmierci" (M. Heidegger) ma przywilej samowiedzy, wie, że jest bytem przygodnym, ale stara się o tym nie pamiętać. Pomaga mu w tym współczesna kultura, zagłuszająca lęki egzystencjalne, dostarczająca tematów zastępczych, wypełniająca czas rozrywką i konsumpcją. Masowe media banalizują śmierć, epatują seryjnymi obrazami śmierci, tak licznymi i brutalnymi, że dochodzi do habituacji. W życiu realnym śmierć nie jest naturalnym, ostatnim etapem życia, jest czymś wstydliwym, co należy skryć za kulisami rzeczywistości. Chory najczęściej umiera w szpitalu (za parawanem albo w izolatce), w towarzystwie urządzeń medycznych i obcego personelu. Zamiast słów modlitwy odmawianej przez najbliższych, słyszy jednostajny rytm monitora rejestrującego zanikające funkcje życiowe. „Czyż jest coś bardziej dehumanizującego niż umieranie w samotności, wśród maszyn, zamiast w otoczeniu bliskich?”, pyta Ritzer, ubolewając nad „makdonaldyzowaniem śmierci” (Ritzer 2009, s. 269).

Czy Polacy na co dzień myślą o przemijaniu? Chcąc znaleźć odpowiedź na to pytanie warto odwołać się do wyników ogólnopolskich sondaży. W raporcie CBOS-u z 2012 roku czytamy: „Wprawdzie niemal trzy czwarte Polaków (72\%) deklaruje, że myśli o śmierci, jednak większości z nich (52\%) zdarza się to rzadko. Co czwarty badany (28\%) twierdzi, że nigdy nie zastanawiał się nad tymi sprawami. W ciągu ostatniej dekady refleksyjność nad śmiercią 
nieznacznie się zmniejszyła - ubyło osób deklarujących, że myślą o niej często (od 2001 roku spadek o 9 punktów, do 20\%), a przybyło takich, którym w ogóle się to nie zdarza (o 6 punktów)" (Komunikat CBOS, W obliczu śmierci. BS/165/2012, grudzień 2012, opracowała Natalia Hipsz, s. 1).

Zaskakiwać może fakt, że w katolickim kraju ponad $70 \%$ ankietowanych życzyłoby sobie „nagłej i niespodziewanej śmierci" (to wbrew modlitwom Kościoła powtarzanym cyklicznie choćby podczas procesji Bożego Ciała); tylko 20\% respondentów wolałoby mieć czas na przygotowanie się do odejścia ze świata. Pośród tej drugiej kategorii osób zdecydowanie dominuje potrzeba pożegnania się z bliskimi, rodziną i przyjaciółmi (81\%), ważnym motywem jest też motyw religijny (71\% pragnęłoby wyspowiadać się i przyjąć przed śmiercią sakramenty). W dalszej kolejności wskazywano na potrzebę uporządkowania spraw majątkowych (62\%) i pogodzenia się z osobami, z którymi respondent jest w konflikcie (42\%). Co czwarta osoba chciałby w czasie oczekiwania na kres życia zapewnić sobie miejsce na cmentarzu, a co dziesiąta pragnęłaby spełnić swoje marzenie, np. wyjechać w daleką podróż.

Niemniej zdecydowana większość badanych życzyłaby sobie nagłego odejścia we śnie (60\%), ponieważ bardziej boimy się cierpienia niż samego unicestwienia. Wymownie pisał o tym Tadeusz Kotarbiński (zm. w 1981 r.), nazywając świadomość nieuchronnego zgonu „uciążliwym przywilejem negatywnym”. Ludzi cechuje „niechęć do przykrości samego procesu zanikania, dla którego obyczajowa formuła sprawozdawcza zna tylko dwie formy alternatywne: <po długich i ciężkich cierpieniach> lub <po krótkich, lecz ciężkich cierpieniach> (Kotarbiński, s. 387-389). Sam fakt śmierci nie powinien- zdaniem autora Medytacji o życiu godziwym - specjalnie zaprzątać umysłu człowieka i generować lęku: „Na zmartwienie $\mathrm{z}$ powodu własnego zgonu będzie czas po fakcie, ale wtedy, na szczęście, po prostu nie będziesz umiał przeżyć żadnego w ogóle zmartwienia". To typowo sokratejskie i epikurejskie podejście do zagadnienia skończoności człowieka, jednak nie niweluje strachu bądź obawy człowieka przed niewiadomą „rzeczy ostatecznych”. Rację miał Karl Jaspers, gdy pisał, że śmierć jest sytuacją graniczną, a w każdym człowieku „drzemie trwoga”. Trzeba dodać, że ankietowani Polacy nie chcą umierać w szpitalu (taką ewentualność aprobuje tylko 8\%), większość (66\%) wolałby $\mathrm{w}$ tym momencie przebywać we własnym domu, a $4 \%$ badanych wskazało na inne miejsca (wyjazd zagraniczny, na łonie przyrody, w wypadku, w pracy, itp) (Komunikat CBOS, s. 4).

\section{Przemysł funeralny - pomiędzy tradycją a nowoczesnością}

G. Ritzer uważa, że niemal każda dziedzina współczesnej kultury podlega makdonaldyzacji, także w sferze funeralnej można zaobserwować przejawy innowacji, które mają usprawnić działania, zwięk- szyć wydajność, zaoszczędzić czas, zracjonalizować system organizacji pochówków (2009). Za kalkulacyjnością, efektywnością kryje się komercja, chęć zysku, reifikacja stosunków interpersonalnych. Dynamicznie rozwijający się przemysł funeralny oferuje różne sposoby pochówku bliskich, od tradycyjnego po kremację i pogrzebanie w urnie, aż po nietypowe formy, m.in. przerobienie prochów na diament, wysłanie ich w przestrzeń kosmiczna w specjalnej metalowej kapsule (http://technowinki.onet.pl/aktualnosci/pochowaj-bliskich-w-kosmosie/lhls1 (data dostępu: 2.11.2014). W naszym kraju działa Polskie Stowarzyszenie Pogrzebowe, które organizuje w Poznaniu Targi Memento. ${ }^{4}$ Przedsiębiorcy pogrzebowi oferuja m.in. trumny $\mathrm{z}$ wikliny, trumny $\mathrm{z}$ wizerunkiem Jana Pawła II, urny z drewna, kamienia i metalu (o różnych kształtach i barwach), małe relikwiarze na prochy bliskich. Także w tej dziedzinie, jak zauważają publicyści, zaczyna obowiązywać moda: „Modnie ubrany i umalowany nieboszczyk, ułożony $\mathrm{w}$ modnej trumnie $\mathrm{z}$ modnym wbiciem, może na cmentarz dojechać modnym samochodem. Tam modnie odziani panowie złożą jego ciało w grobie (obudowanym potem modnym nagrobkiem). Modna zaczyna być również kremacja, bo prochy zmarłego można - przesypane do modnej urny i mniejszych relikwiarzy - postawić w domu na honorowym miejscu" (http://wiadomosci.wp.pl/gid,10594588,gpage,23,img,10594617,kat,1342,title,Moda-pogrzebowa,galeria.html (data dostępu: 2.11.2014). Jeśli chodzi o kwestię pozostawienia prochów zmarłego w domu, jak na razie jest ona bardzo kontrowersyjna. Na podstawie dyskusji internautów można przytoczyć argumenty jej zwolenników i przeciwników. Zwolennicy chwalą pomysł ze względów praktycznych - nie trzeba wychodzić z domu, by odwiedzać groby bliskich, czasem zlokalizowane w odległości setek kilometrów, po drugie jest to tani sposób pochówku. Niektórzy woleliby, aby cmentarze w ogóle zniknęły z polskiego pejzażu.

Przykład podzielonych opinii stanowią poniższe wypowiedzi, pochodzące $\mathrm{z}$ wpisów na forach internetowych: http://wiadomosci.wp.pl/kat,1518,title,Polacy-o-trzymaniu-prochow-bliskich-w-domuco-za-glupota (data dostępu: 2.11.2014):

\footnotetext{
${ }^{4}$ W katalogu targów wyodrębniono wiele kategorii: „maszyny, sprzęt, urzadzenia techniki cmentarnej; budownictwo cmentarne i wyposażenie - projektowanie i wykonawstwo (obiekty do spopielenia zwłok, kostnice, kaplice, nisze i kolumbaria, grobowce); akcesoria cmentarne i pogrzebowe (trumny, urny, odzież dla żałobników i pracowników cmentarzy); oprogramowanie dla administracji cmentarzy (prowadzenie ksiag, map geodezyjnych cmentarza, ewidencji pochowanych osób i przychodów finansowych, rezerwacja miejsc na cmentarzu, wyznaczanie kwater oraz mogił, bieżąca kontrola właściwego usytuowania mogił, grobów i pomników); transport: środki transportu (karawany, wózki, windy, kapsuły, nosze itd.) i usługi transportowe (przewozy): zieleń (projektowanie, wycinka i pielęgnacja drzew, krzewów i zieleni, pielęgnacja i utrzymanie grobów, kompostowanie odpadów roślinnych); BHP (nadzór inwestorski, nadzór nad ekshumacją); usługi pogrzebowe (organizacja pochówku zmarłych), komunalne (wywóz nieczystości stałych, opróżnianie szamb, utrzymanie czystości i porządku na cmentarzu, zimowe utrzymanie alejek i dróg, utrzymanie wodociągu i kanalizacji), kamieniarskie, budowlane, konserwatorskie, dozór cmentarza, poligraficzne i inne". http://www.mementopoznan.pl/pl/ necropolis_w_pigulce/o_targach/ (data dostępu: 2.11.2014).
} 
Bardzo dobry pomyst. Dziś rzadko kto pozostaje $w$ miejscu, gdzie się urodził, albo gdzie sq rodzice pochowani. Większość społeczeństwa za praca udaje się $w$ różne strony świata i odwiedzanie grobów bliskich pozostaje tylko 1 listopada. Kogo przy dzisiejszych cenach paliwa stać na to, żeby kilka razy $w$ roku odwiedzać groby rodzinne odlegle o $450 \mathrm{~km}$, jak jest w moim przypadku. Teraz jest już za późno, ale w przyszłości cieszyłbym się, gdyby moje dzieci, przy mojej urnie w ogrodzie, zapalały świeczkę - Kuba;

Jestem „za”, uważam, że trzeba iść z duchem czasu. A takie rozwiqzanie jest korzystne, przede wszystkim dla starszych, którzy nie mają sił chodzić na cmentarz, chociaż bardzo tego chcą. Myślę, że warto coś takiego wprowadzić, zwłaszcza, że na cmentarzach jest coraz mniej miejsca. To może być dobra dodatkowa opcja przy wyborze miejsca spoczynku - Marika;

W końcu kościół przestanie zdzierać z ludzi ostanie grosze, a w miejscach cmentarzy - molochów powstanq osiedla, albo inne pożyteczne budynki - Nick.

Przeciwnicy takich praktyk podkreślają, że urny z prochami w domu mogą być kłopotem dla następnych pokoleń, a pochowanie ciała w ziemi jest najlepszym sposobem okazania szacunku zmarłemu:

Pomysł z trzymaniem urny $w$ domu uważam za niefortunny. Wszystko jest dobrze, dopóki żyje ktoś, kto zatrzymał urnę ze swoim bliskim. Ale co będzie, gdy i na niego przyjdzie kolej? Spadkobierca znajdzie jakąś urnę w mieszkaniu i co z nia zrobi? Zapewne wyrzuci na śmietnik. Ja mogę mieć życzenie zatrzymać prochy rodziców, ale czy moje dzieci i następne pokolenia zechcą? Albo może każde następne pokolenie będzie mieć stale rosnący zbiór urn: rodziców, dziadków, pradziadków, prapradziadków. Intencją autorów obecnie obowiązujących przepisów było zapobieżenie tego typu sytuacji. I tak powinno pozostać - Internauta;

Macie jakąś gwarancję, że podczas waszej nieobecności $w$ domu, dzieciaki nie zrobiq sobie imprezy z posypywaniem głów, albo sporządzaniem drinków z prochami babci? - Real.

Wśród uczestników sondażu przeprowadzonego przez Wirtualną Polskę były też osoby, którym bliska jest idea rozrzucenia prochów zmarłych, np. w lesie, na morzu, w ogrodzie. Są także entuzjaści wykorzystania prochów w produkcji diamentu (tamże):

Popieram, też nie mam zamiaru leżeć pod jakimś zwaliskiem betonu i marmuru, na wysypisku zniczy, ale w jakimś sympatycznym miejscu (las, łąka, strumyk), więcej mi nie trzeba - Wacek.

Jestem katolikiem, ale chciałabym żeby moje prochy rozsypane zostały w lesie. Kocham las! Gdy jestem w lesie to jestem szczęśliwa - Leśny duszek;

Moja siostra zażyczyła sobie pochowek $w$ morzu, bez płaczu i lamentów. Wykupiłem rejs - weekend na mo- rzu i w drodze powrotnej zatopiłem amforę z niepalonej gliny w Bałtyku, przy dźwiękach Kasi Nosowskiej. Miejsce mam zaznaczone na GPS. Kilku pasażerów było zachwyconych tym, co robię. Amfore siostra zamówiła $w$ Liceum Plastycznym z motywami bluszczu-As.

A ja z moich prochów zlecę dzieciom wyprodukowanie brylancika i będę nadal błyszczeć, ale jako skarb - Sawianka47.

Współcześnie wzrasta znaczenie osób wykonujących zawód tanatopraktora. Przygotowuje on zmarłych na uroczystość pogrzebu, robi profesjonalny makijaż, układa fryzurę, maluje paznokcie, czasem balsamuje ciała zmarłych, wstrzykując do ich żył roztwór soli powstrzymujący rozwój bakterii, a tym samym zapobiegający rozkładowi ciała. Zmienia się „moda funeralna”, okazuje się, że zmarłych nie obowiązuje już strój galowy. Znamienna jest wypowiedź jednego z polskich specjalistów tej branży: „Ubierałem już chyba we wszystko. We fraki, suknie ślubne i balowe, szaty kapłańskie, mundury służbowe, koszulki z logiem ulubionego wokalisty, dżinsy, bluzy z kapturem, a nawet dres i trampki (...) To również trend, który przyszedł do nas zza oceanu, gdzie coraz częściej widuje się oryginalne pochówki. Tam mało kogo dziwi strój czy też kształt trumny, w której jest pochowany zmarły. W Polsce jednak pewne rzeczy są jeszcze nie do przyjęcia, trudno sobie bowiem wyobrazić, czy rodzina zmarłego nie wyszłaby z kościoła na widok ciała pochowanego w replice puszki piwa, czy coca-coli light (...) Zdarza się jednak, że rodzina prosi mnie, aby do trumny włożyć jakiś przedmiot, który był bliski zmarłemu np. ćwiartka wódki, karty do gry, zdjęcia czy maskotki." http://wiadomosci.wp.pl/page,3,title,Zwierzenia-wizazysty-nieboszczykow,wid,10507816,wiadomosc.html (data dostępu: 2.11.2014).

Inny przedstawiciel przemysłu funeralnego odnotował:

„Znam przypadki, gdy rodzina wkładała krzyżówkę, długopis i okulary miłośnikowi takiej rozrywki, była też włożona ulubiona gazeta (...) Czasami ludzie wkładają papierosy i zapalniczkę, małe dzieci rysują kartki, laurki dla zmarłych, czasami są też zdjęcia rodzinne. Zdarzało się, że pod poduszkę chowano piwo czy piersiówkę z tym, co lubił popijać. Zdziwiła nas kiedyś prośba pani, która chowała matkę. Matka była zmarzluchem, więc poprosiła, żeby do trumny ubrać ją w płaszcz i kozaki oraz okryć kołdrą" (http://gazetylokalne.pl/a/strzelce-opolskie-moda-wkracza-na-cmentarze (data dostępu: 2.11.2014).

Na podstawie obserwacji obyczajowości funeralnej w Polsce chciałbym zwrócić uwagę na procesy indywidualizacji pożegnań (np. rodzina zamawia trębacza, bądź innego instrumentalistę, który wykonuje na pogrzebie ulubiony utwór zmarłego). Jeden z właścicieli zakładu pogrzebowego relacjonował: „Klientka poprosiła żałobników, żeby zamiast grudek ziemi na urnę rzucali płatki kwiatów, które były przygotowane na tacy. Ta pani też zamówiła firmę, żeby sfil- 
mowała pogrzeb" (tamże). Warto odnotować, że pojawiła się także w Polsce nowa usługa- relacja z pogrzebu on-line. Jeśli ktoś nie może uczestniczyć na żywo w ostatniej drodze zmarłego, może być obecny na uroczystości wirtualnie, poprzez internetowy przekaz (jest on dostępny tylko dla osób znających odpowiednie hasło).

W Polsce buduje się coraz więcej krematoriów, w 2008 roku działało 9 spopielarni, w 2014 roku 26, w 2016 r. jest ich już 45 (http://oi.hostoi. com/1_6_0-krematoriach-w-Polsce.html (data dostępu: 2.11.2014); ww.krzysztof.waw.pl/index.php/ $\mathrm{pl} /$ Lewe-menu/Krematoria-w-Polsce (data dostępu: 12.06.2016). Statystycznie dominują jednak w Polsce pogrzeby tradycyjne, bowiem kremacja wciąż pozostaje kwestią ambiwalentną. Kościół zaleca formę dotychczasową, choć nie formułuje bezwzględnego zakazu spalania ciał zmarłych. Stanowisko „instytucji strzegącej wiary i obyczajów" wobec kremacji relewantne jest dla wielu polskich katolików. Kodeks Prawa Kanonicznego z 1983 roku zaleca wiernym tradycyjny sposób grzebania ciał zmarłych (ciało określane jest jako świątynia Ducha Świętego), ale dopuszcza także kremacje ,,jeżeli nie została wybrana z pobudek przeciwnych nauce chrześcijańskiej", tzn. jeżeli nie jest wyrazem braku wiary w zmartwychwstanie ciała. ${ }^{5}$ Często o kremacji decydują względy praktyczne - łatwiej jest umieścić urnę w istniejącym już grobie, niż wykupić nowe miejsce na cmentarzu. Niektórzy uważają, że wzrost zainteresowania Polaków kremacją (według danych Polskiego Stowarzyszenia Kremacyjnego w 2000 roku wykonano 6 tys. kremacji, a w 2010 roku już około 21 tys. http:// wiadomosci.wp.pl/page,2,title,Kosciol-dementuje-informacje-o-kremacji,wid,13979701,wiadomosc. html (data dostępu: 5.11.2014) wynika ze względów ekonomicznych, jest to niewątpliwie tańsza od tradycyjnej forma pochówku. ${ }^{6}$

\section{Polskie wzory kultywowania pamięci o zmarłych}

W Polsce tylko na początku listopada media nie stronią od refleksyjnego namysłu nad skończonością

\footnotetext{
${ }^{5}$ Przed zabiegiem kremacji zwłoki muszą być zidentyfikowane przez "członków rodziny. Przygotowanie ciała odbywa się tak, jak w przypadku pochówku tradycyjnego, przy czym może ono zostać owinięte płótnem na wzór całunu. Sam proces spopielenia zwłok jest prowadzony indywidualnie dla każdej osoby zmarłej, umieszczonej w specjalne trumnie kremacyjnej pozbawionej warstwy lakieru, kleju i ozdób z innych tworzyw. W trumnie nie wolno pozostawiać żadnych dodatkowych przedmiotów, pamiątek po zmarłym, a także rozruszników serca i innych implantów. Rodzina może obserwować moment wprowadzania trumny do pieca krematoryjnego $\mathrm{w}$ specjalnie przeznaczonym do tego celu pomieszczeniu. W wypadku kremacji ostatnie pożegnanie z udziałem rodziny i wspólnoty odbywa się przed spopieleniem ciała, by dać możliwość ostatniego realnego kontaktu z osobą zmarłą. Na życzenie rodziny możliwa jest również Msza Święta, obecność celebransa, który poprowadzi liturgię i dokona pokropku. W geście pożegnania do trumny wkładane sa pojedyncze kwiaty. Urnę z prochami umieszcza się w specjalnie do tego celu stworzonym grobie lub kolumbarium w asyście najbliższej rodziny zmarłego." http://ariamemoria.com/ kosciol-katolicki-a-kremacja-zmarlych (data dostępu: 2.11.2014).

W większych miastach za rozmaite usługi związane z pochówkiem płaci się od 7,5 do 9 tys. zł. Zasiłek pogrzebowy - to 4 tys. zł. Najtańszy pogrzeb np. na Cmentarzu Północnym w Warszawie kosztuje 5,5 tys zł." http/http://wiadomosci.wp.pl/kat,1342,title,Polakow-nie-stac-na-pogrzeby (data dostępu: 5.11.2014).
}

i metafizycznym lękiem człowieka. Podtrzymują nastrój zadumy poprzez specjalnie wybraną na te dni ofertę programową. Można mówić o wyjątkowym charakterze listopadowych świąt poświęconych zmarłym celebrowanych w naszym kraju (cmentarze pełne wiązanek, stroików, kolorowych zniczy; modlitwy za zmarłych indywidualne oraz msze i wypominki). Pamięć o tych, którzy odeszli kultywują w dniu Wszystkich Świętych niemal wszyscy Polacy (97\%), ale trzeba zaznaczyć, że niewiele mniej, bo według deklaracji $88 \%$ odwiedza cmentarz bez specjalnej okazji, bądź w rocznicę śmierci, urodzin lub imienin zmarłego (82\%) (na podstawie sondażu przeprowadzonego przez Instytut Badań Opinii RMF w 2012 roku; http//FUNEr/Wszystkich Swiętych i Zaduszki ważne dla większości Polaków - Polska - Fakty w RMF24 (data dostępu: 2.11.2014).

Pierwszego listopada Kościół katolicki obchodzi uroczystość zarówno świętych oficjalnie uznanych (kanonizowanych), jak i anonimowych świętych, niewyniesionych na ołtarze. Ponieważ jest to dzień ustawowo wolny od pracy, Polacy gremialnie uczestniczą w celebrowaniu święta, jedni biorą udział we mszy świętej (biały kolor liturgicznych szat kapłanów podkreśla radosny i uroczysty charakter tego dnia), inni ograniczają się do odwiedzin bliskich na cmentarzu. ${ }^{7}$ W tych dniach Polacy masowo podróżują na groby bliskich, często pokonując setki kilometrów. Dla osób indyferentnych w kwestiach wiary jest to -tak jak w czasach komunistycznych - świeckie Święto Zmarłych, dla homo religiosus święto o charakterze religijnym. De facto dopiero następny dzień - Dzień Zaduszny- poświęcony jest wszystkim zmarłym, nie tylko tym, którzy już -według terminologii religijnej- „osiągnęli niebo”. Najgorliwsi korzystają z przewidzianych na okres oktawy odpustów (przez osiem dni przybywaja na cmentarz i odmawiają modlitwy za zmarłych. Jak naucza Kościół, jeden taki akt uwalnia jedną duszę z czyśćca). ${ }^{8}$

Polacy kultywują pamięć o zmarłych nie tylko w listopadowe święta, jak wynika z badań, ponad 16 $\%$ odwiedza cmentarze raz $\mathrm{w}$ miesiącu, tyle samo kilka razy w miesiącu, a co dziesiąty badany odwiedza groby bliskich jeszcze częściej (tamże). Dane te świadczą niewątpliwie o szczególnej obyczajowości Polaków, o zachowaniach podkreślających łączność z bliskimi, którzy odeszli (nawet osoby niereligijne $\mathrm{w}$ tradycyjnym sensie wyrażają nieraz wiarę $\mathrm{w}$ istnienie jakiejś formy pozagrobowego bytowania ich bliskich). Polacy nie zastąpili tradycji importowanym z Zachodu świętem Halloween, choć przyznać trzeba, że także w Polsce przybywa z roku na rok entuzjastów jego celebrowania (31 października). Ponieważ

\footnotetext{
W uroczystość Wszystkich Świętych na polskich nekropoliach zbierane są ofiary na renowację nagrobków. Kwestują znane postaci życia publicznego, aktorzy, dziennikarze, itd. Dzięki tym datkom możliwe jest zachowanie zabytkowych grobów przed niszczycielskim działaniem czasu.

${ }^{8}$ Kontrowersyjną jest kwestia czy polskie nekropolie, zarzucone sztucznymi i żywymi kwiatami, wieńcami i stroikami, przepełnione płonacymi zniczami stanowia miejsca pamiecci o bliskich wyrafinowane pod względem estetycznym (w niektórych przypadkach przydałoby się trochę umiaru, bowiem można mniemać ważniejsze wydaje się zamanifestowanie przed znajomymi hojności niż chwila refleksji nad przemijaniem i wyrażenie miłości do osób, które już odeszły)
} 
każda okazja do zabawy jest pożądana w „konsumpcyjnym społeczeństwie doznań", także i w naszym kraju młodzi ludzie przebierają się za mroczne postaci z filmów grozy, duchy, wampiry, diabły, czarownice; zdarza się, że na wzór kolegów ze Stanów Zjednoczonych, Kanady, Wielkiej Brytanii czy Irlandii chodzą od domu do domu zbierając cukierki. Dla jednych Halloweeen jest sposobem „oswajania ze śmiercią", przezwyciężania lęku, dla innych promocją pogaństwa, a nawet satanizmu. Alternatywą dla pogańskiego i pozbawionego elementu sacrum $\mathrm{Hal}$ loween (ostro krytykowanego przez Kościół) jest organizowany, także w Polsce, tzw. Korowód Swiętych - przemarsz ulicami miast ludzi przebranych za znanych świętych Kościoła. Biorą w nim udział przedstawiciele wszystkich pokoleń - z zapalonymi świecami, flagami z wizerunkami osób kanonizowanych modla się i śpiewają religijne pieśni. Ideą obchodów Holy Wins (Swięty Zwycięża) jest próba zainteresowania Polaków życiem ludzi oficjalnie uznanych za świętych. Organizatorzy takiej formuły świętowania tłumaczą: „Holy Wins ma promować radość, piękno, dobroć i .życie, a nie strach, brzydotę, zło i śmierć" (http://polki.pl/we-dwoje/holy;wins;zamiast;halloween,artykul,34864.htm (data dostępu: 2.11.2014). Jest to dobra okazja do przypomnienia nauki Kościoła „o świętych obcowaniu”, o życiu wiecznym.

Osobnego omówienia wymagają wzory zachowań na gruncie tradycji i kultury, m.in. obrzędy i zwyczaje związane ze śmiercią, kontynuowane w niektórych rejonach kraju po dziś dzień (zwłaszcza na wsiach). Umierającemu wkładano w dłonie zapalona gromnicę. Zmarły przebywał w domu ułożony w trumnie na prowizorycznym katafalku otoczonym świecami; domownicy i sąsiedzi zbierali się wokół niego na modlitwę i śpiewanie żałobnych pieśni. Wyprowadzano zmarłego (ułożonego nogami w stronę wyjścia) i w kondukcie żałobnym odprowadzano do kościoła na mszę. Po pogrzebie obowiązkowym aktem zamykającym uroczystość była stypa żałobna. Warto wspomnieć jeszcze o zatrzymywaniu zegarów w domu w momencie śmierci domownika, o zakrywaniu luster. Obecnie specjalistyczne zakłady pogrzebowe odbierają ciało zmarłego ze szpitala, przygotowują na ostatnią drogę i zawożą na cmentarz. Wszystko dzieje się szybko, sprawnie, zgodnie z nowoczesnymi procedurami zestandaryzowanymi w branży pogrzebowej.

\section{Internet jako źródło społecznego wsparcia w okresie żałoby}

Socjologowie odnotowują stopniowe zanikanie w społeczeństwie więzi społecznych, opartych na bliskości przestrzennej. Fragmentaryzacja życia zbiorowego, indywidualizacja, dezintegracja i społeczna anomia to procesy charakterystyczne dla współczesnej kultury. Zdaniem niektórych badaczy Internet zabiera czas, który dawniej był zarezerwowany dla rodziny i przyjaciół, tym samym osłabia istniejące więzi (por. Slouka 1995; Haber 2011). Z drugiej stro- ny możemy mówić o powstaniu nowego typu więzi, które Piotr Sztompka nazwał wirtualnymi (Sztompka 2012:115; Zimnica-Kuzioła 2015). Symptomatyczne, że w okresie żałoby niektórzy poszukują wsparcia nie $w$ najbliższym otoczeniu, ale $w$ wirtualnym świecie. Liczne fora (np. skupiające osoby po stracie dziecka) dają szansę ekspresji nagromadzonych emocji i powrotu do psychicznej równowagi. Internet oferuje osobom przeżywającym stratę bliskich, pogrążonym w żałobie, konkretną pomoc, dostarczając wielu informacji związanych z problematyką funeralną. Powstają wirtualne cmentarze, na których można zapalić wirtualną świeczkę, by „odnaleźć spokój ducha". Portale oferują szerokie spectrum usług - osoba, która przeżywa żałobę po odejściu kogoś bliskiego może za ich pośrednictwem zamieścić nekrolog w prasie, może też złożyć kondolencje, wykupić usługę opieki nad wybranym grobem, zamówić kwiaty na pogrzeb. Istnieje też możliwość zamieszczenia epitafium, zaprezentowania krótkiej biografii osoby zmarłej, pokazania jej wyjątkowości, a także zamieszczenia jej zdjęć oraz materiałów audio i video. ${ }^{9}$ Można też włączyć funkcję przypominania rodzinie i bliskim o rocznicy śmierci osoby zmarłej. Zadbano także o pomoc psychologiczną dla osób cierpiących po stracie bliskich - zgromadzono zbiór artykułów specjalistycznych z konkretnymi poradami (można też zamówić indywidualną konsultację psychologiczną). Osobne miejsce zajmują porady prawne („m. in. na temat testamentu, spadku, zachowku, dziedziczenia, pogrzebu, itp."). Internet stanowi jednocześnie kompendium wiedzy i źródło informacji na temat konkretnych firm, instytucji i osób związanych $\mathrm{z}$ dziedziną funeralną (pogrzebowych, kamieniarskich, kwiaciarni, cmentarzy, hospicjów, grup wsparcia, psychologów, prawników) (http://ariamemoria.com (data dostępu: 6.11.2014). Okazuje się, że z usług firm działających w przestrzeni Internetu korzystają także ci, którzy mają potrzebę pożegnania $\mathrm{w}$ ten niekonwencjonalny sposób ludzi nie znanych im osobiście, reprezentujących strefę publiczną ${ }^{10}$.

\section{Zakończenie}

W obliczu Tanatosa człowiek jest bezradny, każdy musi oswoić lęk, zmierzyć się z rudymentarnym problemem śmierci własnej i ludzi mu bliskich. Roman Ingarden w Ksiqżeczce o człowieku pisał, że świadomość skończoności czyni los człowieka tragicznym, ów lęk egzystencjalny nie jest możliwy do wyeliminowania. Niemniej nie proponował on ucieczki od tego, co nieuniknione: „Niepokój usunie chyba ten,

\footnotetext{
${ }^{9} \mathrm{~W}$ promocyjnej cenie ( $240 \mathrm{zł}$ ) można też zamówić multimedialne wspomnienie o zmarłym w postaci cyfrowej. Wystarczy dostarczyć do firmy odpowiednie materiały (zdjecia, aforyzmy, itd.), które profesjonalni graficy opracowują wizualnie (do wyboru są trzy szablony z określonymi animacjami) i akustycznie (wzbogacając muzycznym podkładem).

${ }^{10} \mathrm{~Np}$. po śmierci Anny Przybylskiej na portalu pojawiły się wspomnienia $o$ artystce, zapalono wirtualne znicze. $W$ jej pogrzebie uczestniczyły tysiące ludzi (nie bez znaczenia był fakt, że była to osoba znana z mediów, „mieszkanka masowej wyobraźni”, w dodatku młoda matka, która osierociła trójkę małych dzieci). Osoby, które nie mogły uczestniczyć w pogrzebie aktorki, -za pośrednictwem Internetu- wyraziły swój smutek i żal z powodu jej odejścia.
} 
kto poczuje w samym sobie ślady bytu niepodległego czasowi - przemijaniu. By ślad ten w sobie odnaleźć, trzeba umieć przy sobie pozostać bez lęku zatraty siebie w czasie i bez ulegania pozorowi bycia rzeczą na świecie. Pozostać zaś przy sobie, to znaczy nie tylko zwiększyć samowiedzę własnego <ja> w różnych jego kolejach, lecz nadto mieć się we władzy swojej i w starciu z przeciwnościami losu, z sobą, z zagadnieniami życia budować siebie samego jako wciąż wzmagającą się moc wewnętrzną. Zaufać sobie i swemu istnieniu. Wówczas też zmieni się oblicze czasu. Staje się on tylko okazją pozwalającą człowiekowi na ugruntowanie w sobie swego ducha" (Ingarden, s. 334).

Wraz z przemianami współczesnych społeczeństw zmieniają się też wzory kulturowe dotyczące śmierci i umierania, można mówić o instytucjonalizacji śmierci, o jej tabuizacji. Jednak lęk przed śmiercią nie jest możliwy do zagłuszenia - kanalizowany w społeczeństwie nastawionym na konsumpcję i hedonizm, dochodzi do głosu choćby w przestrzeni Internetu. Trafnie rzecz ujmuje jedna z blogerek: „Z jednej strony coraz więcej jest przypadków izolowania chorych i cierpiacych, kojarzenia umierania z czymś nieestetycznym, przekazywania wyspecjalizowanym jednostkom organizacyjnym ostatniego etapu życia członków rodziny, unikania rozmów na trudne tematy, trywializacji zagadnienia $w$ mediach. Z drugiej strony śmierć wciąż stanowi inspirację dla artystów (kinematografia, fotografika, literatura, malarstwo i grafika, coraz częściej ludzie młodzi tworza i słuchaja piosenek o umieraniu), w Internecie samorzutnie powstaja grupy dyskusyjne, systematycznie prowadzone sa pełne refleksji blogi, a cmentarze, które kilkanaście lat temu były licznie odwiedzane tylko $w$ dzień Wszystkich Świętych, stały się obecnie miejscem częstych i bezokazjonalnych wizyt" (blog Joanny Nowak, http://przepisane-ze-swojej-szuflady.bloog.pl/id,339531204,title,Kilka-socjologicznych-pytan-na-temat-smierci,index.html (data dostępu: 7.11.2014).

Obserwacja socjologiczna pozwala odnotować zmiany, jakim podlega polskie społeczeństwo po upływie niemal trzech dekad od transformacji ustrojowej. W Polsce można mówić o ciągłości tradycji, o kultywowaniu pamięci o tych, którzy odeszli, niemniej także i ta dziedzina ludzkiego życia podlega innowacjom. Niewątpliwie duża jest rola dziedzictwa kulturowego (m.in. nadal silna pozycja Kościoła i dominacja jego dyskursu na temat śmierci), które wpływa na etos Polaków (świadczy o tym choćby przewaga liczebna pogrzebów o obrządku religijnym, zamawianie mszy i tzw. „wypominków” za zmarłych). Kościół przestrzega: memento mori, ale jednocześnie daje nadzieję i podstawę do optymistycznego stwierdzenia: non omnis moriar. Nie sposób przecenić działań ludzi zaangażowanych w ruch hospicyjny, których poświęcenie przywraca godność człowiekowi umierającemu. Jednocześnie zmianom ulegają formy zachowań - ze starymi, tradycyjnymi wzorami koegzystują nowe wzory (internetowe fora, blogi, instytucje działające w przestrzeni wirtualnej) i treści (znaczenia świeckie wypierające religijne sensy). Można mówić o okcydentalizacji zwyczajów związanych z dziedziną śmierci i umierania (np. rosnąca ilość kremacji, duża rola przemysłu funeralnego), ale i o trwałości rodzimych wzorów, pokazujących respekt dla przeszłości, dla zbiorowej tożsamości Polaków.

\section{Literatura:}

1. Benedict R. (2008), Wzory kultury. Wydawnictwo Muza, Warszawa.

2. Drążkiewicz J. (1989), W stronę człowieka umierającego. O ruchu hospicjów w Polsce. Uniwersytet Warszawski, Instytut Socjologii, Warszawa.

3. Durkheim E. (2011), Samobójstwo. Studium z socjologii. Oficyna Naukowa, Warszawa.

4. Gałuszka M., Szewczyk K. (red.) (1996), Umierać bez lęku. Wstęp do bioetyki kulturowej. Wydawnictwo Naukowe PWN, Warszawa.

5. Haber L. (2011), Technologie informacyjne jako źródło patologii w społeczeństwie informacyjnym, W: C. Hales, B. Mikuła (red.), Społeczeństwo informacyjne. Gospodarka, technologia, procesy, Wydawnictwo Uniwersytetu Ekonomicznego, Kraków, s. 61-70.

6. Ingarden R. (2000), Człowiek i czas, W: B. Ogrodnik, Ingarden. Wiedza Powszechna, Warszawa, s. 316-338.

7. Jarosz M. (1997), Samobójstwa. Wydawnictwo Naukowe PWN, Warszawa.

8. Kłoskowska A. (1980), Kultura masowa. Krytyka i obrona, PWN, Warszawa.

9. Kolbuszowski J. (red.) (2002), Problemy współczesnej tanatologii. Medycyna - Antropologia Kultury - Humanistyka. Wrocławskie Towarzystwo Naukowe, tom VI, Wrocław.

10. Kolbuszowski J. (red.) (2004), Problemy wspótczesnej tanatologii. Medycyna - Antropologia Kultury - Humanistyka. Wrocławskie Towarzystwo Naukowe, tom VIII, Wrocław.

11. Komunikat CBOS, W obliczu śmierci, BS/165/2012, grudzień 2012, opracowała Natalia Hipsz.

12. Kotarbiński T. (1987), Pisma etyczne. red. P. J. Smoczyński, Ossolineum, Wrocław.

13. Kubler-Ross E. (1979), Rozmowy o śmierci i umieraniu. Media Rodzina, Poznań.

14. Ogryzko-Wiewiórowska M. (1992), Rodzina w obliczy śmierci. Studium socjologiczne. Wyd. UMCS, Lublin.

15. Ostrowska A. (2002), Umieranie i śmierć, W: Encyklopedia Socjologii, t. 4, Oficyna Naukowa, Warszawa, s. 271-273.

16. Ostrowska A. (2005), Śmierć w doświadczeniu jednostki i społeczeństwa. Wydawnictwo IFiS, Warszawa.

17. Ritzer G. (2009), Makdonaldyzacja społeczeństwa. Wydanie na nowy wiek. Wydawnictwo Muza, Warszawa.

18. Skrzypek M. (2011), Perspektywa chorego w socjologii choroby przewlekłej. Wyd. KUL, Lublin. 
19. Slouka M. (1995), War of the Worlds: Cyberspace and the High-tech Assault on Reality. Basic Books, New York.

20. Sztopmka P. (2012), Socjologia. Analiza społeczeństwa. Społeczny Instytut Wydawniczy Znak, Kraków.

21. Zimnica-Kuzioła E. (2015), Więzi społeczne w społeczności wirtualnej - przykład internetowego forum, W: U. Swadźba, B. Pactwa, M. Żak (red.), Praca-więź-integracja. Wyzwania w życiu jednostki i społeczeństwa. Monografia poświęcona pamięci prof. zw. dr. hab. Władysława Jachera, t.1, Praca, przedsiębiorczość, gospodarka oparta na wiedzy, Wydawnictwo Uniwersytetu śląskiego, Katowice, s. 275-288.

\section{Źródła internetowe:}

1. http://technowinki.onet.pl/aktualnosci/pochowaj-bliskich-w-kosmosie/lhls1 (data dostępu:2.11.2014).

2. http://www.mementopoznan.pl/pl/necropolis_w_pigulce/o_targach/ (data dostępu: 2.11.2014).

3. http://wiadomosci.wp.pl/gid,10594588,gpage,23,img,10594617,kat,1342,title,Moda-pogrzebowa,galeria.html (data dostępu: 2.11.2014).

4. http://wiadomosci.wp.pl/page,3,title,Zwierzenia-wizazysty-nieboszczykow,wid,10507816,wiadomosc. html (data dostępu: 2.11.2014).

5. http://gazetylokalne.pl/a/strzelce-opolskie-moda-wkracza-na-cmentarze (data dostępu: 2.11.2014).

6. http://oi.hostoi.com/1_6_O-krematoriach-w-Polsce.html (data dostępu: 2.11.2014).

7. http://wiadomosci.wp.pl/page,2,title,Kosciol-dementuje-informacje-o-kremacji,wid,13979701,wiadomosc.htm (data dostępu: 5.11.2014).

8. http/http://wiadomosci.wp.pl/kat,1342,title,Polakow-nie-stac-na-pogrzeb (data dostępu: 5.11.2014).

9. http://ariamemoria.com/kosciol-katolicki-a-kremacja-zmarlych (data dostępu: 2.11.2014).

10. http://gazetylokalne.pl/a/strzelce-opolskie-moda-wkracza-na-cmentarze (data dostępu: 2.11.2014).

11. http//FUNEr/Wszystkich Świętych i Zaduszki ważne dla większości Polaków - Polska - Fakty w RMF24 (data dostępu: 2.11.2014).

12. http://wiadomosci.wp.pl/kat,1518,title,Poacy-o-trzymaniu-prochow-bliskich-w-domu-co-za-glupota (data dostępu: 2.11.2014). 